\title{
CLINICAL FEATURES AND OUTCOME IN CHILDREN WITH LANGERHANS CELL HISTIOCYTOSIS. A SINGLE INSTITUTION EXPERIENCE FROM PAKISTAN
}

\author{
Nida Noor, Rabia Muhammad Wali, Anis-Ur-Rehman, Muhammad Abu Bakar \\ Shaukat Khanum Memorial Cancer Hospital \& Research Centre, Lahore Pakistan
}

\section{ABSTRACT}

Objective: To find out the clinical manifestations, treatment given and outcome of children with diagnosis of Langerhans cell histiocytosis.

Study Design: Retrospective observational study.

Place and Duration of Study: Shaukat Khanum Cancer Hospital, Lahore Pakistan, from Jan 2005 to Dec 2015.

Methodology: Medical charts were reviewed in detail along with the available imaging for the patients. The data included age at the time of diagnosis, extent of the disease, involvement of risk organs, treatment given, response at 6th week of chemotherapy and at the end of the treatment, and outcome in terms of disease progression during the treatment, relapse of disease on follow up and cause of death either due to treatment related mortality or disease complications.

Results: There were 29 patients, 12 patients $(41 \%)$ had single system and $17(58 \%)$ had multisystem involvement. 7 patients $(41 \%)$ had risk organ involvement in the multisystem group. All the patients of multisystem and 6 patients of single system were treated according to the Langerhans cell histiocytosis III protocol. Commonest sites of involvement were bone in 22 $(75 \%)$, followed by lymph nodes in 18 (62\%) patients. Disease relapse was seen in 6 patients and all of them had multisystem disease. Mortality was observed only in multisystem Langerhans cell histiocytosis patients and more than 50\% were risk organ positive.

Conclusion: Langerhans cell histiocytosis is a highly heterogeneous disease. Some forms are curable without chemotherapy, while the multisystem disease requires aggressive treatment. However, despite intensive treatment, the multisystem disease and risk organs involved have poor prognosis. In our study, overall survival and event free survival in multisystem Langerhans cell histiocytosis is lower as compared to the Western literature.

Keywords: BRAF mutation, Multi system langerhans cell histiocytosis, Risk organ, Single system langerhans cell histiocytosis.

How to Cite This Article: Noor N, Wali RM, Rehman AU, Bakar MA. Clinical Features and Outcome in Children with Langerhans Cell Histiocytosis. A Single Institution Experience from Pakistan. Pak Armed Forces Med J 2021; 71(6): 2194-2201. Doi: https://doi.org/10.51253/pafmj.v71i6.4022

This is an Open Access article distributed under the terms of the Creative Commons Attribution License (https://creativecommons.org/licenses/by-nc/4.0/), which permits unrestricted use, distribution, and reproduction in any medium, provided the original work is properly cited.

\section{INTRODUCTION}

Langerhans cell Histiocytosis (LCH) is an inflammatory myeloid neoplasm with deposition of abnormal Langerhans cells in different organs. ${ }^{1}$ Previously $\mathrm{LCH}$ was thought to be caused by immune dysregulation, however, after the recent discovery of BRAF oncogenic mutation, in more than half of the LCH patients it has now been called clonal myeloid neoplasm. ${ }^{2}$

$\mathrm{LCH}$ is a very rare disorder with the annual incidence of 5-6 cases per million in children. ${ }^{3}$ Most common sites of involvement arebones, skin, lymph nodes, lungs, liver, spleen, bone marrow and brain. ${ }^{4}$ It has a wide spectrum of clinical manifestations ranging from localized self-limited disease to rapidly pro-gressive and disseminated multisystem disease that might lead to death. ${ }^{5}$ At present, LCH is classified based on the extent of organ systems involved at diagnosis. Single system disease (SS-LCH) (involvement of one organ or

Correspondence: Dr Nida Noor, Pediatric Oncology Dept, Shaukat Khanum Memorial Hospital \& Research Centre, Lahore Pakistan Received: 19 Mar 2020; revision received: 21 Aug 2020; accepted: 31 Aug 2020 system) most commonly involves skin and bone but can involve other organ systems as well. Single system involvement can be unifocal or multifocal in nature and have an excellent prognosis but patients with multisystem disease (MS-LCH) (involvement of two or more risk organ systems) have an unpredictable course and is associated with a poor prognosis. ${ }^{6}$

Treatment of $\mathrm{LCH}$ depends on the site and extent of disease at diagnosis, it may include clinical examination and observation on follow up, surgery, systemic chemotherapy or radiotherapy. ${ }^{7}$ The aim of the study was to find out the clinical manifestations, treatment given, response to the treatment and clinical outcome in children with the diagnosis of $\mathrm{LCH}$.

\section{METHODOLOGY}

This analysis wasa retrospective review of the children registered at the Shaukat Khanum Memorial Cancer Hospital Lahore, with a biopsy-proven diagnosis of LCH, from January 2005 and December 2015. Institutional Review Board approval was obtained (IRB Ltr No. Exmpt-05-06-18-01) and 29 patients were 
included in this study using the non-probability consecutive sampling technique.

Inclusion Criteria: Patients of either genderwith biopsy-proven diagnosis of Langerhans cell histiocytosis $(\mathrm{LCH})$ were included.

Exclusion Criteria: Patients of more than 18 years of age were excluded.

Medical charts were reviewed in detail along with available imaging for these patients. The data included age at the time of diagnosis, extent of the disease (single or multi-system), involvement of risk organs (liver, lungs, spleen and hematopoietic system with or without bone marrow involvement), treatment given, response to chemotherapy on reassessment, at 6 week of initial course 1 and at the end of treatment and outcome in terms of disease progression during the treatment, relapse of the disease on follow upand cause of death either due to treatment related mortality or disease complications.

All the patients were evaluated with the help of history, physical examination, complete blood count, serum electrolytes, urine analysis, skeletal survey, chest $\mathrm{x}$-ray, liver function tests, bone marrow aspiration (in the case of bicytopenia or pancytopenia), abdominal ultrasonography (USG) and cranial computerized tomography (CT) scan. Magnetic resonance imaging (MRI) was done only for thecases where there were neurological symptoms or suspicion of lesion on skull and spinal X-ray. Positive emission tomography (PET-CT) was performed in only 2 cases and Deauville scoring was done for the metabolic activity.

All the patients who received chemotherapy were treated on LCH III protocol 8and as per the protocol, the patients with a single or multifocal bone lesion, isolated skin or solitary lymph nodeor CNS involvement were regarded as single-system disease (SS-LCH). Involvement of more than one system with or without risk organs involvement (liver, spleen, lungs, hematopoietic system with or without bone marrow involvement) is defined asmultisystem disease. Liver dysfunction is defined as hypoproteinemia $<5.5 \mathrm{~g} / \mathrm{dL}$ and hypoalbuminemia $<2.5 \mathrm{~g} / \mathrm{dL}$, not due to other causes. Hematopoietic system dysfunction is defined as hemoglobin levels $<10 \mathrm{~g} / \mathrm{dL}$ and/or platelet count $<100 \times$ $10^{9} / \mathrm{L}$ and/or total leukocyte count $<4 \times 10^{9} / \mathrm{L}$. Treatment includes local surgery, systemic chemotherapy, a combination of these modalities or observation only.

Chemotherapy given in SS-LCH with multifocal bone disease, CNS lesion risk (lesion in the orbital, temporal/mastoid, sphenoidal, zygomatic, ethmoidal bones, maxilla, sinuses or anterior or middle cranial fossa, with intracranial soft tissue extension) and in patients with multi-system disease with or without risk organ involvement. Re-assessment is done after initial course 1 after 6 weeks as per LCH III protocol. ${ }^{8}$ Disease response is usually classified as 1) Active Disease $(\mathrm{AD})$ better, incase of regression of the diseaseor no active disease (NAD) with resolution of all signs and symptoms, 2) AD worse, in case of progression of the disease, 3) AD intermediate, in case of stable or mixed response with new lesions at one site and regression at another site.

Patients with MS-LCH received initial course 1 for 6 weeks and were continued on Continuation chemotherapy if they had NAD after initial course 1 and those who had $\mathrm{AD}$ better or $\mathrm{AD}$ intermediate, received initial course 2 for 6 weeks and re-assessed after 12 weeks, and were continuedon continuation chemotherapy for 12 months from the start of the treatment if they were AD better or NAD. Those who had AD intermediate or $\mathrm{AD}$ worse after 12 weeks of initial course 1 and 2, treatment escalated to salvage regimen as per the LCH III protocol schema (Table-I).

Patients with SS-LCH received IC-1 for 6 weeks; they were then continued on maintenance chemotherapy for 12 months from the start of the treatment if they had NAD or AD better, second course of induction was given only in case of $\mathrm{AD}$ worse or intermediate (Table-I).

Initial course 1 consists of oral prednisone $40 \mathrm{mg}$ / $\mathrm{m}^{2}$ divided in 3 doses daily for 4 weeks then tapering in 2 weeks and injection vinblastine $6 \mathrm{mg} / \mathrm{m}^{2}$ day 1 of every week for 6 weeks.

Initial course 2 consists of oral prednisone in 3 divided doses for 3 days every week, from week 7-12 and injection vinblastine, day 1 of week 7-12.

Continuation treatment is for 12 months which consists of oral 6-mercaptopurine $50 \mathrm{mg} / \mathrm{m}^{2}$ daily and oral prednisone $40 \mathrm{mg} / \mathrm{m}^{2}$ in 3 doses, day $1-5$ every 3 weeks, injection vinblastine $6 \mathrm{mg} / \mathrm{m}^{2}$ day 1 every 3 weeks.

Salvage regimen consists of 6 or 12 weeks course of initial chemotherapy depending on response at 6 weeks, patients who had NAD after initial course 1 were continued on continuation chemotherapy for 12 months and those who had AD better or intermediate received second course of initial chemotherapy for another 6 weeks. 
Table-I: Treatment plan for multi-system and single system langerhans cell histiocytosis.

\begin{tabular}{|c|c|c|c|}
\hline \multicolumn{4}{|c|}{ Multisystem Langerhans Cell Histiocytosis } \\
\hline Interval & Evaluation & Response & Therapy \\
\hline \multirow{4}{*}{ Week 6} & \multirow{4}{*}{$\begin{array}{l}\text { After Initial } \\
\text { Course-1 }\end{array}$} & $\begin{array}{l}\text { No Active } \\
\text { Disease }\end{array}$ & $\begin{array}{c}\text { Continuation } \\
\text { treatment }\end{array}$ \\
\hline & & Better & $\begin{array}{c}\text { Initial treatment } \\
\text { course } 2\end{array}$ \\
\hline & & Intermediate & $\begin{array}{c}\text { Initial treatment } \\
\text { course } 2\end{array}$ \\
\hline & & Worse & Salvage \\
\hline \multirow{4}{*}{$\begin{array}{l}\text { Week } \\
12\end{array}$} & \multirow{4}{*}{$\begin{array}{c}\text { After Initial } \\
\text { Treatment } \\
\text { Course } 2\end{array}$} & $\begin{array}{l}\text { No Active } \\
\text { Disease }\end{array}$ & $\begin{array}{c}\text { Continuation } \\
\text { treatment }\end{array}$ \\
\hline & & Better & $\begin{array}{c}\text { Continuation } \\
\text { treatment }\end{array}$ \\
\hline & & Intermediate & Salvage \\
\hline & & Worse & Salvage \\
\hline \multirow{4}{*}{$\begin{array}{l}\text { Week } \\
24\end{array}$} & \multirow{4}{*}{$\begin{array}{c}\text { During } \\
\text { Continuation } \\
\text { Treatment }\end{array}$} & $\begin{array}{c}\text { No Active } \\
\text { Disease } \\
\text { Better } \\
\end{array}$ & $\begin{array}{l}\text { Continuation } \\
\text { treatment }\end{array}$ \\
\hline & & $\begin{array}{c}\text { Intermediate } \\
\text { without } \\
\text { Risk organ. } \\
\text { intermediate } \\
\text { with Risk } \\
\text { organ. }\end{array}$ & $\begin{array}{c}\text { Continuation } \\
\text { treatment } \\
\text { Salvage }\end{array}$ \\
\hline & & $\begin{array}{c}\text { Worse } \\
\text { without } \\
\text { Riskorgan. }\end{array}$ & Salvage \\
\hline & & $\begin{array}{l}\text { Worse with } \\
\text { Riskorgan }\end{array}$ & Salvage \\
\hline $\begin{array}{l}\text { At } 12 \\
\text { Month }\end{array}$ & $\begin{array}{c}\text { End of } \\
\text { Continuation } \\
\text { Treatment } \\
\end{array}$ & $\begin{array}{l}\text { No Active } \\
\text { Disease }\end{array}$ & Stop treatment \\
\hline \multicolumn{4}{|c|}{ Single System Langerhans Cell Histiocytosis } \\
\hline \multirow{4}{*}{ Week 6} & \multirow{4}{*}{$\begin{array}{l}\text { After Initial } \\
\text { Course-1 }\end{array}$} & $\begin{array}{l}\text { No Active } \\
\text { disease }\end{array}$ & Continuation \\
\hline & & Better & Continuation \\
\hline & & Intermediate & $\begin{array}{c}\text { Initial treatment } \\
\text { course } 2\end{array}$ \\
\hline & & Worse & $\begin{array}{c}\text { Initial treatment } \\
\text { course } 2\end{array}$ \\
\hline \multirow[t]{3}{*}{$\begin{array}{l}\text { Week } \\
12\end{array}$} & $\begin{array}{l}\text { After Initial } \\
\text { Course-2 }\end{array}$ & $\begin{array}{l}\text { No active } \\
\text { disease } \\
\text { Better }\end{array}$ & Continuation \\
\hline & & Intermediate & Continuation \\
\hline & & Worse & Salvage \\
\hline
\end{tabular}

Initial courses 1 and 2 consist of oral prednisone and injectionvinblastine doses same as above with methotrexateinfusion $500 \mathrm{mg} / \mathrm{m}^{2}$ day 1 of week $1,3,5$.

Continuation treatment consists of oral 6-mercaptopurine, prednisone and methotrexate $\left(20 \mathrm{mg} / \mathrm{m}^{2}\right.$ once weekly until the end of month 12). Doses and schedule of 6-mercaptopurine and prednisone is same asabove described in continuation chemotherapy for MS-LCH.
Four patients of MS-LCH without risk organ involvement initially treated on LCH III protocol, after disease relapse, treated on LCH IV protocol stratum II, consist of initial chemotherapy of oral prednisone, injection vincristine and cytarabine for 12 weeks and continuation chemotherapy with oral 6-mercaptopurine and methotrexate and the total duration of treatment was 2 years.

All the patients with SS-LCH and MS-LCH were followed after completion of treatment every 4-6 weeks for one year then 6 monthly up to 3-5 years, with clinical examination, blood tests, x-rays of bony lesions, ultrasound if there was involvement of liver and spleen and MRI brain in case of diabetes insipidus or CNS risk lesions.

Statistical analysis was carried out using the Statistical Package for social sciences (SPSS) version 23. Kaplan Meier was used to estimate the overall and event free survival (EFS). Overall survival (OS) was calculated as time from diagnosis to death or last visit. EFS was calculated as time from diagnosis to death, progression of the disease or relapse, which ever came first on last visit.

\section{RESULT}

There were 29 patients including 21 male (72.4\%) and 8 female patients $(27.6 \%)$. The mean age at diagnosis was $6 \pm 3.8$ years. Four patients $(13.7 \%)$ were under the age of 24 months andall of them had multi system disease. There wasone twin pair in the study group.

The most common complaint at the time of presentation was lymphadenopathy followed by bone pain and fever shown in the Table-II. 50\% Unifocal

Table-II: Presentingcomplaints of patients at presentation.

\begin{tabular}{l|c}
\hline Presenting Complaints & $\mathbf{n} \mathbf{( \% )}$ \\
\hline Lymphadenopathy & $14(48 \%)$ \\
Bone pain / pain in extremity & $6(20.6 \%)$ \\
Fever & $4(13.7 \%)$ \\
Orbital/para orbital mass with proptosis & $2(6.8 \%)$ \\
Swelling at maxilla & $1(3.4 \%)$ \\
Scalp swelling & $2(3.4 \%$ \\
Ulcerative skin lesion at labia majora & $1(3.4 \%)$ \\
Dermatitis & $1(3.4 \%)$ \\
Supraclavicular Mass & $1(3.4 \%)$ \\
Ulcerative perianal skin and muscle & $1(3.4 \%)$ \\
Retro auricular swelling with hard palate & \\
involvement. & $1(3.4 \%)$ \\
Abdominal Distention & $2(6.8 \%)$ \\
Diabetes insipidus & $3(10.3 \%)$ \\
Ear Discharge & $1(3.4 \%)$ \\
Inguinal mass & $1(3.4 \%)$ \\
\hline
\end{tabular}


bone involvement was seen in 3 patients and multifocal bone involvement was seen in 3 patients, lymph node involvement in 5 patients $(41 \%)$, whereas 1 patient had isolated ulcerated skin lesion on genitalia (8.3\%).

Single system involvement at the time of diagnosis was present in 12 patients (41\%), their clinical features are shown in Table-III(A). Most common system involved were bones in 6 patients. Seventeen patients (58\%) had multisystem disease.

Of the 17 patients with MS-LCH, bones were most frequently involved in $94 \%$ of patients, with skull $(52 \%)$ being the most common. Lymphnodes were involved in $76 \%$ of patients. Hypothalamus-pituitary axis was involved in $4(23 \%)$ patients, $2(11 \%)$ at the time of presentation whereas $1(6 \%)$ patient developed CNS lesion on relapse and another one in disease progression.

Seven patients $(42 \%)$ presented with risk organ involvement, the most common site was hematopoietic system in 4 patients $(23 \%)$, out of which bone marrow involvement was positive in 3 patients $(17 \%)$. Liver involvement was seen in 3 patients $(17 \%), 2$ patients $(11 \%)$ presented with hepatomegaly with hepatic dysfunction while $1(6 \%)$ patient had hepatic dysfunction only. More than one risk organ involvement was seen in 3 patients. Risk organ involvement distribution is described in detail in Table-IIIB.

Figure-1, shows that in SS-LCH, out of 12 patients, 3 were with multifocal bone disease, 1 with ulcerative skin lesion at labia majora (painful and progressive lesion), and 2 with CNS risk lesion and were treated with systemic chemotherapy, whereas $50 \%$ of patients were monitored clinically on follow up without any therapy. Those who received systemic chemotherapy, at re-assessment after initial course 1 (6 weeks), 1 of them had NAD, while 5 patients $(83 \%)$ had AD better. All the patients were continued on continuation treatment for 12 months. At the end of treatment reassessments cans after 12 months showed that all of them $(100 \%)$ had complete regression of disease. No disease recurrence or relapse was seen in all patients with single system disease until last follow up. In MS$\mathrm{LCH}$, there were 10 patients $(58.8 \%)$ without risk organ involvement. AD better was achieved in 9 patients and 1 patient had $\mathrm{AD}$ intermediate at reassessment after 6 weeks of initial course of chemotherapy. At the end of treatment re-assessment, 9 patients $(90 \%)$ were in complete remission while one of the patient had disease progression whoinitially presented with multifocal
Table-III(A): Clinical characteristics of patients with langerhans cell histiocytosis.

\begin{tabular}{|c|c|c|c|c|}
\hline & \multicolumn{2}{|c|}{$\begin{array}{l}\text { Single System } \\
\text { Langerhans cell } \\
\text { Histiocytosis }\end{array}$} & \multicolumn{2}{|c|}{$\begin{array}{l}\text { Multi system } \\
\text { Langerhans Cell } \\
\text { Histiocytosis }\end{array}$} \\
\hline No. of Patients & \multicolumn{2}{|c|}{$12(41 \%)$} & \multicolumn{2}{|c|}{$17(58.6 \%)$} \\
\hline $\begin{array}{l}\text { Gender } \\
\text { Distribution }\end{array}$ & $\begin{array}{c}\text { Males: } \\
10(83 \%)\end{array}$ & $\begin{array}{l}\text { Females: } \\
2(16.6 \%)\end{array}$ & \begin{tabular}{|c|} 
Male: \\
$11(64.7 \%)$
\end{tabular} & $\begin{array}{l}\text { Female: } \\
6(35 \%)\end{array}$ \\
\hline \multicolumn{5}{|c|}{ Age at Diagnosis } \\
\hline $0-2$ years & \multicolumn{2}{|c|}{-} & \multicolumn{2}{|c|}{$8(47 \%)$} \\
\hline $2-10$ years & \multicolumn{2}{|c|}{$8(66.6 \%)$} & \multicolumn{2}{|c|}{$9(52.9 \%)$} \\
\hline$>10$ years & \multicolumn{2}{|c|}{$4(33.3 \%)$} & \multicolumn{2}{|c|}{ - } \\
\hline
\end{tabular}

\section{Site of Involvement}

\begin{tabular}{l|c|c}
\hline Bone n=22 & $6(50 \%)$ & $16(94 \%)$ \\
\hline Unifocal n=10 & $3(50 \%)$ & $7(44 \%)$ \\
\hline Multifocal $n=12$ & $3(50 \%)$ & $9(52.9 \%)$ \\
\hline $\begin{array}{l}\text { Skull Lesion } \\
\mathrm{n}=11\end{array}$ & $2(33 \%)$ & $9(52.9 \%)$ \\
\hline $\begin{array}{l}\text { Lymph nodes } \\
\mathrm{n}=18\end{array}$ & $5(41 \%)$ & $13(76 \%)$ \\
\hline Skin n=3 & $1(8.3 \%)$ & $2(11 \%)$ \\
\hline $\begin{array}{l}\text { Multi-system } \\
\text { Langerhans Cell }\end{array}$ & - & $7(41 \%)$ \\
$\begin{array}{l}\text { Histiocytosis } \\
\text { with Risk Organ } \\
\text { Involvement }\end{array}$ & - & $2(11 \%)$ \\
\hline Lungs & - & $3(17 \%)$ \\
\hline Liver & - & $1(11 \%)$ \\
\hline Spleen & - & $3(17 \%)$ \\
\hline $\begin{array}{l}\text { Hematopoietic } \\
\text { system without } \\
\text { bone marrow } \\
\text { involvement }\end{array}$ & - & \\
\hline $\begin{array}{l}\text { Hematopoietic } \\
\text { system with } \\
\text { Bone marrow } \\
\text { involvement }\end{array}$ & - & \\
\hline $\begin{array}{l}\text { CNS involvement } \\
\text { at presentation }\end{array}$ & - & \\
\hline
\end{tabular}

Lab Results

\begin{tabular}{l|c|c}
\hline Anemia $\mathrm{HB}<10$ & - & $2(6.8 \%)$ \\
\hline Bicytopenia & - & $2(6.8 \%)$ \\
\hline Pancytopenia & - & $1(3.4 \%)$ \\
\hline $\begin{array}{l}\text { Elevated } \\
\text { Transaminase }\end{array}$ & - & $3(10 \%)$ \\
\hline Hypoalbuminemia & - & $3(10 \%)$ \\
\hline Hyperbilirubinemia & - & $3(10 \%)$ \\
\hline
\end{tabular}

Table-III(B): Risk organ distribution in 7 patients with multi-system langerhans cell histiocytosis.

\begin{tabular}{l|c|c|c|c|c|c|c}
\hline Risk Organs & 01 & 02 & 03 & 04 & 05 & 06 & 07 \\
\hline Liver & $+\mathrm{ve}$ & +ve & & +ve & & & \\
\hline $\begin{array}{l}\text { Hematopoietic system } \\
\text { Bone Marrow positive }\end{array}$ & $+\mathrm{ve}$ & $+\mathrm{ve}$ & $+\mathrm{ve}$ & & & & \\
\hline $\begin{array}{l}\text { Hematopoietic system } \\
\text { Bone Marrow negative }\end{array}$ & & & & $+\mathrm{ve}$ & & & \\
\hline Spleen & & & & $+\mathrm{ve}$ & $+\mathrm{ve}$ & & \\
\hline Lungs & & & & & & +ve & +ve \\
\hline
\end{tabular}


bone lesion with pituitary involvement and diabetes insipidus. The patient escalated tosalvage chemotherapy but died during initial course1 due to disease progression. Of the 10 patients without risk organ involvement, disease relapse was seen in 3 patients $(30 \%)$ after the $1^{\text {st }}$ line of chemotherapy, one of them relapsed at 19-months post treatment in CNS and developed diabetes insipidus during the treatment. He was treated with cytarabine $\left(150 \mathrm{mg} / \mathrm{m}^{2} /\right.$ day $)$ for 1 year and had been in remission until the last follow up. The other two who relapsed within one year of the end of therapy, were treated on LCH IV protocol stratum-II. One patient is under treatment while another one has completed the treatment and is in remission till last follow up. There were 7 patients (41\%) with risk organ involvement including the twin sisters. On reassessment after initial course 1 , response was AD better in 5 patients $(71 \%)$ and $\mathrm{AD}$ worse in 2 patients $(28.7 \%)$, the twin sisters were escalated to salvage arm of treatment. At the end of the treatment after 12 months, complete remission was achieved in 6 patients $(85.7 \%)$ whereas one patient continued to have disease progression despite receiving chemotherapy, escalated to salvage che- was seen in 3 patients with risk organ involvement $(42.8 \%)$, Two of these were twin sisters and had more than one risk organ involvement (liver \& hematopoietic system) and at 6 week of re-assessment scan, both of them had AD worse. They were escalated to salvage chemotherapy for 12 weeks and then continued to continuation therapy for 1 year but unfortunately both patients relapsed within one year of completion of treatment. They were treated with LCH IV protocol stratum II and now both the patients are in remission for the last 5 years. One patient with lungs as risk organ involvement had relapsed within one year after completion of chemotherapy, however, the family didn't want to pursue further treatment and left against medical advice. Two patient with risk organ involvement died, one had extensive disease progression during the treatment and another one was an infant (9 months old) who presented with orbital mass with splenic involvement. He died due to pneumonia worsened to septicemia.

Of the total 29 patients, 4 patients (13.7\%) had diabetes insipidus and all of them had multisystem disease, out of which 3 patients presented with diabe-

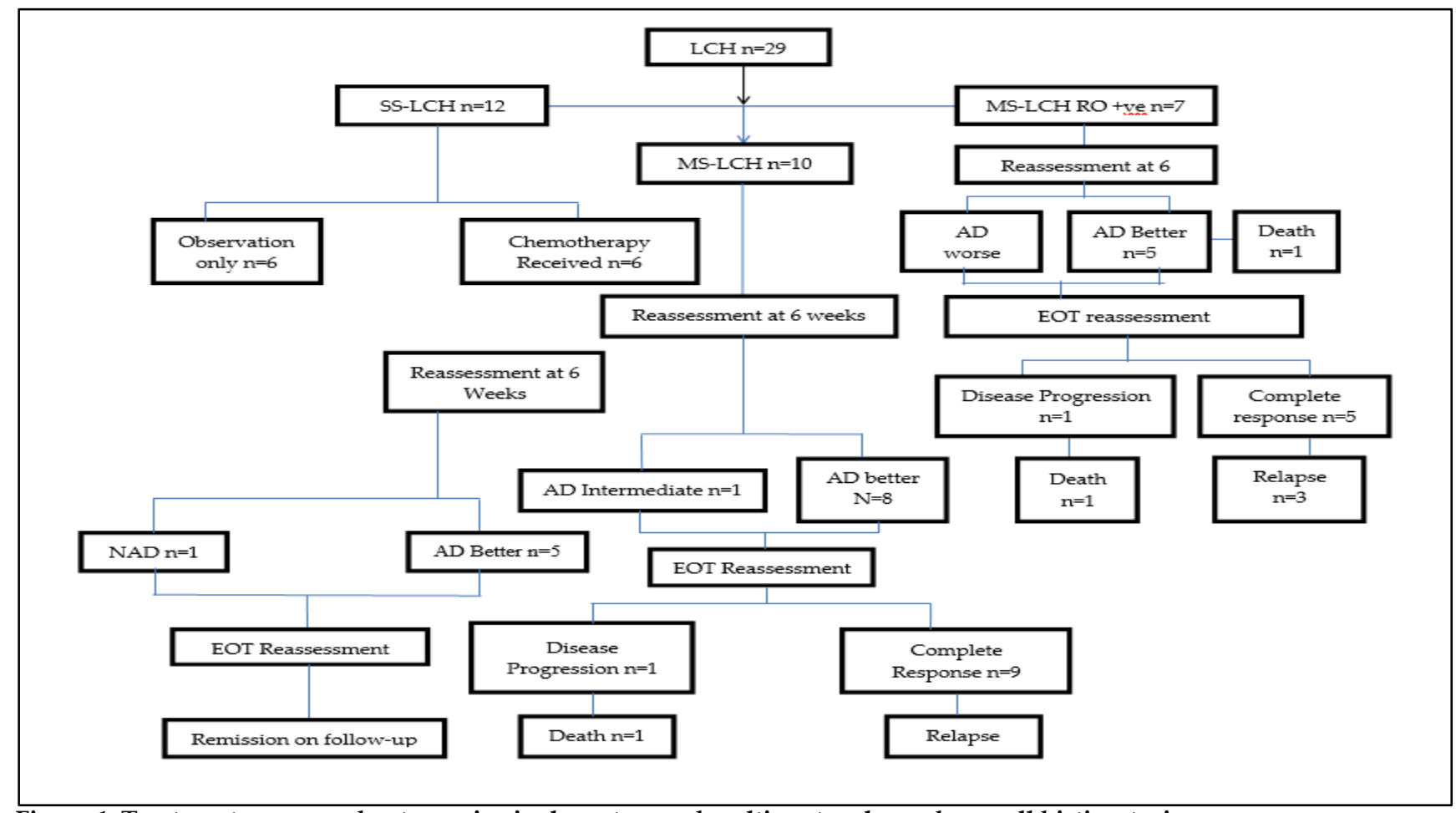

Figure-1: Treatment course and outcome in single system and multi-system langerhans cell histiocytosis.

motherapy but unfortunately died due to extensive disease progression involving the liver, spleen, bone marrow and central nervous system. Disease relapse tes insipidus at the time of presentation, one patient had pituitary involvement and one had hypothalamus involvement at diagnosis and one presented with 
diabetes insipidus without CNS risk lesion while one patient developed diabetes insipidus at relapse after 19 months post treatment with pituitary involvement.

Poor outcome was seen in patients who were risk organ positive as $p$-value $<0.05$. No significance was seen with the involvement of the skull and facial bones with the onset of diabetes insipidus ( $p$-value $>0.05$ ), The overall 3 years survival of single system $\mathrm{LCH}$ is $100 \%$ whereas multisystem LCH was $82.4 \%$. The overall survival of multisystem LCH with risk organ involvement was $71.4 \%$ and without risk organ involvement was $90 \%$. The EFS for SS-LCH was $100 \%$ whereas for MS-LCH was $47 \%$ and EFS with risk organ positive was $28.57 \%$ (Figure-2). may play a role in its development as about $1 \%$ of patients have relatives with $\mathrm{LCH}$, monozygotic twin pairs are concordant for $\mathrm{LCH} .{ }^{10,9}$ In the present study there was one monozygotic twin pair who presented with MS-LCH with risk organ involvement.

The clinical presentation of patients with $\mathrm{LCH}$ varies depending upon the sites and extent of involvement. The most frequently involved organs are the bones $(80 \%)$, skull being the most commonly affected site and painful bony lesions are the most common presentation, involvement of skin in $33 \%$ and the pituitary in $25 \%$ of patients. Other organs involved are the liver, spleen, the hematopoietic system and the lungs $(15 \%$ each), lymph nodes (33\%), the central nervous system
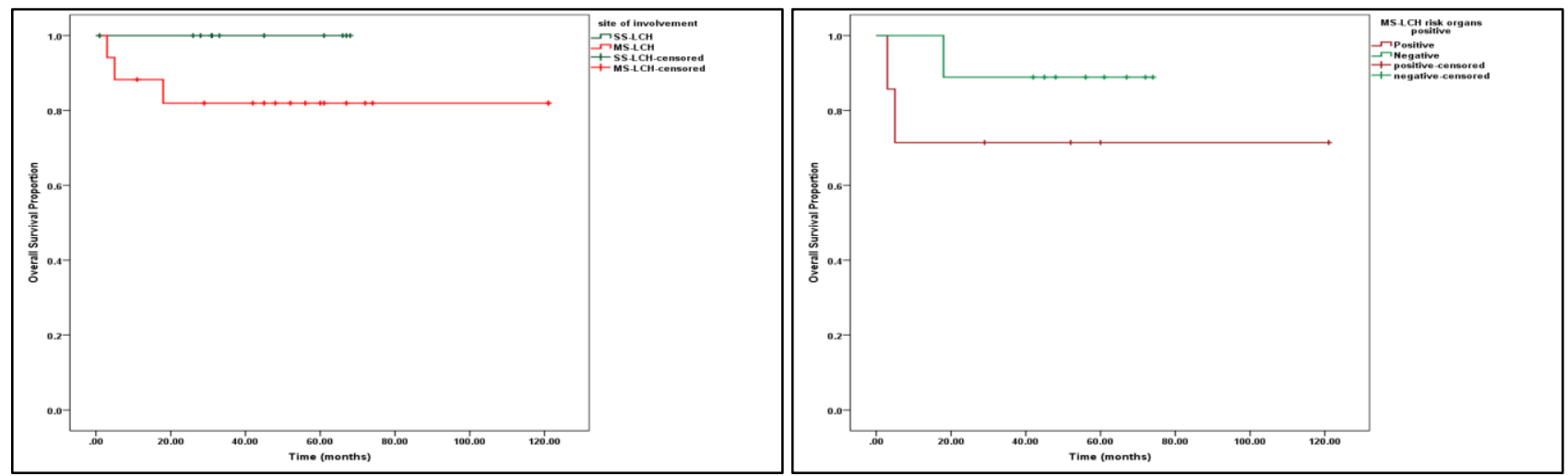

Figure-2: Overall survival of single system and multi system langerhans cell histiocytosis with or without risk organ involvement.

\section{DISCUSSION}

Langerhans cell histiocytosis (LCH) is now called clonally derived neoplasm. Previously it was considered a disorder of immune dysregulation, but the identification of activating mutations in the BRAF-V600E in half ofthe $\mathrm{LCH}$ cases has changed the definition of $\mathrm{LCH}$ to a dendritic cell neoplasm with a strong inflammatory component. ${ }^{9} \mathrm{LCH}$ is a very rare disorder and until now very few studies havebeen published on the outcome of patients with LCH. The largest single center study was published from Turkey on outcome of 217 pediatric patients with $\mathrm{LCH}$ by Yagc1 et al. ${ }^{7}$ Another study published in Turkey by Dilekince et al. reported 20 patients. $^{3}$ In our study there were only 29 patients diagnosed and treated with $\mathrm{LCH}$ during 10 years and most of our patients were within the ages of $2-10$ years (58\%). Similar results have been reported by Shovana et al 10 , in which the male to female ratio was 2.6:1 with male predominance similar to literature. ${ }^{10,3}$ $\mathrm{LCH}$ is a non-hereditary disorder and usually sporadic, but also has some genetic predisposition which excluding pituitary $2-4 \% .11,12$ In our study the most frequently involved organs were bones $76 \%$, among them skull was involved in $50 \%$ of cases and most of patients in our study alsopresented with bone pain. Lymph nodes were second most common involved organ in our study seen in $62 \%$ of patients, contrary to what other literature reported. ${ }^{11}$

Skin lesions are most common manifestation of $\mathrm{LCH}$ and easily misdiagnosed with childhood rashes like seborrheic dermatitis and eczema, ${ }^{13}$ and cutaneous lesions are mostly associated with MS-LCH (53\%). ${ }^{11}$ In the current study, only 3 patients $(10 \%)$ had skin involvement; 2 with ulcerative lesion and 1 with dermatitis and $66 \%$ had multisystem disease.

Liver and spleen involvement are mostly associated with multisystem LCH $15-20 \%$ and have poor prognosis. ${ }^{14,15}$ Patients with liver involvement may present with hepatomegaly or associated hepatic dysfunction. ${ }^{16}$ In this study $17 \%$ ofthe patients had liver involvement, all of them had hepatic dysfunction with multisystem disease at the time of presentation, while 
splenic involvement was seen in $11 \%$ of patients with MS-LCH.

As mentioned above in the results, disease progression after initial chemotherapy and disease relapse was seen in $66 \%$ of patients with liver involvement, while mortality was $50 \%$ with splenic involvement.

Hematopoietic system with bone marrow involvement is very rare in children around $2-7.5 \%$ and mostly associated with multisystem disease andhas poor prognosis. ${ }^{17}$ Yagci et al also reported the worst prognosis in all patients who presented with pancytopenia or leukopenia. ${ }^{7}$

In the current study, out of 17 MS-LCH patients, $23 \%$ had hematopoietic system involvement presented with bi and pancytopenia and bone marrow involvement $(17 \%)$ in, ${ }^{3}$ patients. Mortality was $25 \%$ and disease relapse was seen in $50 \%$ of patients within one year of the end of treatment.

Isolated pulmonary disease is very rare in children $(<1 \%)$ as compared to adults. Pulmonary involvement is mostly associated with multisystem disease. ${ }^{18}$ In the present study, $11 \%$ of patients had pulmonary involvement with MS-LCH. Relapse rate with lung involvement was $50 \%$ in our study. Dilekinc et al reported the relapse rates of four cases with MS-LCH where lung involvement was $3(25 \%)$.

In the recent LCH IV protocol, lung is not considered as a risk organ because death due to lung disease usually occurs due to mechanical complications like pneumothorax or chronic emphysematous changes. ${ }^{12}$

CNS involvement in LCH ranges from 3.4 to $57 \%$. Common sites of involvements are hypothalamic pituitary region and diabetes insipidus is the most common initial manifestation of CNS lesions. ${ }^{19}$ In our analyzed patient population, CNS involvement was seen in 4 (23\%) of cases, among which 2 patients had pituitary and hypothalamus involvement at the time of presentation. The CNS manifestation did not occur alone in none of these patients.

Diabetes insipidus is seen $25 \%$ in $\mathrm{LCH}$, mostly with CNS risk lesion(craniofacial bone lesion). ${ }^{11}$ In the present study we had $13.7 \%$ patients with diabetes insipidus, no significance was seen with the involvement of the skull and facial bones lesions with the onset of diabetes insipidus (as $p$-value was $>0.05$ ).

It has been documented in literature that multisystem disease has higher chances of reactivation and relapse. Another prognostic factor for relapse and re- activation of disease is the response to chemotherapy after six weeks of initial chemotherapy, 15,20 which is similar to our study findings. $20 \%$ (6 out of 29 ) of patients relapsed after the endof treatment, all of them had multisystem disease while half of them were risk organ positive. Those who relapsed, $50 \%$ had inadequate response after 6 weeks of induction and all of them were shifted to 2 nd line of treatment.

Risk organ with multisystem disease has poor survival, ${ }^{20}$ and mortality is $10-50 \%,{ }^{21}$ which is similar to our study results. Three patient $(10 \%)$ died in our study, all were had multi-system disease while two $(66 \%)$ of them were risk organ positive.

It is reported in literature that overall survival of 5 years in patients with single system LCH is $100 \%$ while OS in multisystem disease without risk organ involvement is $98 \%$ and survival rate is $77 \%$ with risk organ involvement at diagnosis ${ }^{16}$ and in LCH III trial overall survival of MS-LCH with risk organ positive was 4 (84\%). In our study, survival was $100 \%$ in patients with SS-LCH which is comparable with the literature while in patients with MS-LCH without risk organ involvement, the OS was $90 \%$ and patients with involvement of risk organ OS was $71.4 \%$ which is lower as compared to the Western literature.

Since 2010, LCH is known to harbor the BRAF activating mutation andthose patients who have BRAF mutations have more chances of disease relapse, reactivation and poor response to standard $\mathrm{LCH}$ chemotherapy. ${ }^{21}$

Cytogenetics of our study population is not known, BRAF mutations might be in context of high rate of consanguineous marriages in our population. Anti BRAF therapy has promising role in recurrent and relapsed LCH. Screening of all patients with MS-LCH for BRAF status and Anti-BRAF targeted therapies should be considered for treatment of such patients in future.

\section{CONCLUSION}

$\mathrm{LCH}$ is a highly heterogeneous disease and some forms are curable without chemotherapy, while multisystem disease requires aggressive treatment. However, despite intensive treatment, multisystem disease and risk organ involvement has poor prognosis. In our study overall survival and event free survival in MS-LCH is lower as compared tothe Western literature.

\section{Conflict of Interest: None.}

\section{Author's Contributions}

NN: Study design, data collection and conception and writing, RMW: Study design and critical analysis and article 


\section{Langerhans Cell Histiocytosis}

writing, AUR: Study conception and critical analysis and data design, MAB: Data collection and interpretation.

\section{REFERENCES}

1. Chow TW, Leung WK, Cheng FW, Kumta SM, Chu WC, Lee V, et al. Late outcomes in children with Langerhans cell histiocytosis. Arch Dis Child 2016; 102(2): 830-835.

2. Allen CE, Merad M, McClain KL. Langerhans-cell histiocytosis. N Engl J Med 2018; 379(9): 856-868.

3. 3.İnce D, Demirağ B, Özek G, Erbay A, Ortaç R, Oymak Y, et al. Pediatric langerhans cell histiocytosis: single center experience over a 17-year period. Turk J Pediatr 2016; 58(4): 349-355.

4. 4.Thacker NH, Abla O. Pediatric Langerhans Cell Histiocytosis: State of the Science and Future Directions. Clin Adv Hematol Oncol 2019; 17(2): 122-131.

5. Allen CE, Ladisch S, McClain KL. How I treat Langerhans cell histiocytosis. Blood 2015; 126(1): 26-35.

6. Kamath S, Arkader A, Jubran RF. Outcomes of children younger than 24 months with Langerhans cell histiocytosis and bone involvement: a report from a single institution. J Pediatr Orthop 2014; 34(8): 825-830.

7. Yağc1 B, Varan A, Çağlar M, Söylemezoğlu F, Sungur A, Orhan D. Langerhans cell histiocytosis: retrospective analysis of $217 \mathrm{ca}-$ ses in a single center. Pediatr Hematol Oncol 2008; 25(5): 399-408.

8. Minkov M, Grois N, McClain K, Nanduri V, Rodriguez-Galindo C. Langerhans cell histiocytosis: Histiocyte Society evaluation and treatment guidelines 2020, [Internet] Available from: http:/ / www.hematologie-amc.nl/bestanden/hematologie/ bijlagennietinDBS/SocietyLCHTreatmentGuidelines.PDF

9. Abla O, Weitzman S. Treatment of langerhans cell histiocytosis: role of BRAF/MAPK inhibition. Hematol Am Soc Hematol Educ Program 2015; 2015(2): 565-570.

10. Karki S, Rajbhandari A. Langerhans cell histiocytosis; an institutional study. J Pathol Nepal 2017; 7(2): 1192-1195.

11. Jezierska M, Stefanowicz J, Romanowicz G, Kosiak W, Lange M. Langerhans cell histiocytosis in children - a disease with many faces. Recent advances in pathogenesis, diagnostic examinations and treatment. Dermatol Alergol 2018; 35(1): 6-8.
12. Haupt R, Minkov M, Astigarraga I, Schäfer E, Nanduri V, Jubran $\mathrm{R}$, et al. Langerhans cell histiocytosis ( $\mathrm{LCH})$ : guidelines for diagnosis, clinical work up, and treatment for patients till the age of 18 years. Pediatr Blood Cancer 2013; 60(2): 175-184.

13. Simko SJ, Garmezy B, Abhyankar H, Lupo PJ, Chakraborty R, Lim KP, et al. Differentiating skin-limited and multisystem Langerhans cell histiocytosis. J Pediatr 2014; 165(5): 990-996.

14. Yi X, Han T, Zai H, Long X, Wang X, Li W, et al. Liver involvement of Langerhans cell histiocytosis in children.Int J Clin Exp Med 2015; 8(5): 7098-7106.

15. Morimoto A, Oh Y, Shioda Y, Kudo K, Imamura T. Recent advances in Langerhans cell histiocytosis. Pediatr Int 2014; 56(4): 451-461.

16. Krooks J, Minkov M, Weatherall AG. Langerhans cell histiocytosis in children: History, classification, pathobiology, clinical manifestations, and prognosis. J Am Acad Dermatol 2018; 78(6): 1035-1044.

17. 17.Kumar M, Sachdeva MU, Naseem S, Ahluwalia J, Das R, Varma $\mathrm{N}$, et al. Bone marrow infiltration in Langerhans cell histiocytosis - An unusual but important determinant for staging and treatment. Int J Hematol Oncol Stem Cell Res 2015; 9(4): 193197.

18. Varkki S, Tergestina M, Bhonsle VS, Moses PD, Mathai J, Korula $\mathrm{S}$. Isolated pulmonary langerhans cell histiocytosis. Ind J Pediat 2013; 80(8): 700-703.

19. Yeh EA, Greenberg J, Abla O, Longoni G, Diamond E, Hermiston $\mathrm{M}$, et al. North American Consortium For Histiocytosis. Evaluation and treatment of langerhans cell histiocytosis patients with central nervous system abnormalities: Current views and new vistas. Pediatr Blood Cancer 2018; 65(1): 12-15.

20. Tokgoz H, Caliskan U. Langerhans cell histiocytosis in children: a single center experience from Turkey. J Am Acad Dermatol 2016; 28(4): 83-88.

21. Sedky MS, Hamouda A, Taha H, Zaky I, Hassanain O, El Hemaly A, et al. Outcome of high-risk langerhans cell histiocytosis (LCH) in Egyptian children, does intermediate-dose methotrexate improve the outcome. J Pediatr Hematol Oncol 2019; 41(8): 635-643. 